\title{
"Kaleak suntsitzen du": bakarrik dauden adingabe atzerritarrak, bakarrik dauden gazte atzerritarrak izatera heltzen direnean, pairatzen dituzten beharrizanak profesionalen ikuspuntutik
}

\author{
Aitziber Castaños Mihi \\ Gizarte-hezitzailea eta gizarte-langilea \\ castanosmihiaitziber@gmail.com \\ Iraia Aguayo Portillo \\ Gizarte-hezitzailea eta gizarte-langilea \\ iraiairaia01@gmail.com
}

\section{Janire Fonseca Peso}

Gizarte Pedagogia eta Dibertsitate Saila, Deustuko Unibertsitatea

Janire.fonseca@deusto.es

Artikulu honen helburua, profesionalen ustez bakarrik dauden adingabe atzerritarrak, bakarrik dauden gazte atzerritarrak izatera heltzen direnean, pairatzen dituzten beharrizanak identifikatzea da. Ikerketa zabalago baten parte da lan hau, Bizkaian bakarrik dauden gazte atzerritarren beharrak identifikatzea helburu zuena. Metodologia kualitatiboan oinarrituz, kasu honetan, kolektibo honekin zerbitzu desberdinetan lan egiten duten hamar profesionalei elkarrizketa sakonen analisia aurkezten da. Elkarrizketa gidoia sortzeko, Eusko Jaurlaritzaren Gizarte Bazterkeria Baliosteko Tresna Tekniko Bateratua oinarri izan zen. Emaitzen artean azpimarratzekoa da laguntza-sare baten sorkuntzaren premia; hots, babes-zerbitzutik kanpo geratzen direnean, bazterketa egoera pairatzeko arrisku handiagoan egonda, gizarte- eta hezkuntzaeskuartzetik, bazterketa honetan eragina duten esparru guztiei aurre egiteko premia.

\section{GAKO-HITZAK:}

Bakarrik dauden adingabe atzerritarrak, bakarrik dauden gazte atzerritarrak, bazterketa, babesgabetasuna, immigranteak, migrazioa, gizartehezkuntza.
El objetivo de este artículo es identificar, desde la percepción de las personas profesionales, las necesidades que sufren los menores extranjeros no acompañados (MENA) cuando pasan a la condición de jóvenes extranjeros no acompañados (JENA). Este trabajo forma parte de una investigación más amplia que tenía como objetivo identificar las necesidades de este colectivo vizcaíno de jóvenes. En este caso, se presenta el análisis de diez entrevistas en profundidad realizadas a profesionales que trabajan con el colectivo en diferentes servicios. Para la elaboración del guion de entrevista, se utilizó el Instrumento Técnico Común de Valoración de la Exclusión Social del Gobierno Vasco. Entre los resultados, subrayamos la necesidad de generar una red de ayuda; es decir, dada la situación de vulnerabilidad en la que se encuentra el colectivo al quedarse fuera del sistema de protección, la necesidad de una intervención socioeducativa en todos los ámbitos y factores que tienen impacto en los procesos de exclusión social.

\section{PALABRAS ClAVE:}

Menores extranjeros no acompañados, jóvenes extranjeros no acompañados, exclusión, desprotección, inmigrantes, migración, educación social. 


\section{Sarrera}

Atal honetan, bakarrik dauden adingabe atzerritarren migrazio-prozesuari buruz arituko gara; izan ere, guri dagokigun kolektiboa, bakarrik dauden gazte atzerritarrak, adingabeak izan dira Espainian kasu gehienetan. Magrebetik bakarrik datozen adingabeen kolektiboari buruz arituko gara, hori baita gure erkidegoan artatzen den kopuruari buruzko profil adierazgarriena (Ararteko, 2011: $94^{1}$, Save the Children, 2017²). Espainiako Abokatutzaren Kontseilu Nagusiareneta Espainiako Unicef-enarabera (2009: 25), bakarrik dauden adingabe atzerritarraren kontzeptua honela definitzen da: "Europar Batasuneko kide ez den estatu bateko adingabea, Espainian sartzean 18 urte baino gutxiago dituen aberrigabea, heldu batekin ez doana. Europar Batasuneko estatu-kide batean (kasu honetan Espainian) sartu ondoren, bakarrik uzten den adingabea ere izango da adingabe atzerritarra”.

Setién eta Barceloren arabera (2008), bakarrik dauden adingabeak immigrazioaren ehuneko portzentual txikia dira, nahiz eta Espainia izan gehien erregistratu dituen herrialdea, Afrikako iparraldetik hurbil dagoelako. Euskadin, bakarrik dauden adingabe atzerritarren kopurua beste autonomiaerkidego batzuetan baino nabarmenagoa da, estatumailan bosgarren postuan (Save the Children, 2017). Ildo horretatik, Arartekoaren datuetan oinarrituta (2011) hurrengo baieztapenak ditugu: harrerasisteman bakarrik dauden adingabe atzerritarren kopurua etengabe hazten ari da, adingabeen jatorria dibertsifikatzen ari da, nahiz eta Magrebeko adingabeak nagusi izaten jarraitzen duen, gero eta kasu gehiago ikusten dira Sahararen hegoaldeko Afrikatik, Europako Ekialdetik edo Hego Ameriketatik. Aldaketak ikusten ari dira migrazio-proiektuan, "ia helduen” emigrazioa izatetik, migrazio-proiektu argi batekin, lan egiteko, bizi-baldintzak hobetzeko eta jatorrizko familiari laguntzeko, "nerabeen" emigrazioa izatera igaro da, proiektu zehatzik gabe.

Bakarrik dauden adingabe atzerritarrak adinez nagusi direnean, autonomo izateko Espainiako gazteriari eragiten dioten zailtasunak izateaz gain, gazte horiek babes-gabezia handiagoa dute, ez baitute familiarik, eta erakunde eta gizarte-laguntza behar dute emantzipazio-prozesua errazteko eta lan-integrazioa bermatzeko (Palma-García, Ruiz Mosquera eta Vives González, 2019). Izan ere, zirkuitu instituzionaletatik kanpo, gazte horiek lan-merkatuan sartzearen bidez lagundu gabe igaro daitezke helduen bizitzara; beraz, hori gertatzen ez denean eta lanaldi osoko urtebeteko lan-kontratua lortu ezin dutenean, egoera irregularrean dauden atzerritarrak dira berriro, eta,

${ }^{1}$ Txostenean agertzen diren datuak: 2003. urtean, gure autonomia erkidegoan harturiko adin txikikoetatik, \% 97 Magrebetik zetozen, eta Saharazko hegoaldeko Afrikako herrialdeetatik, \% 0,8. 2009. urtean, hartutako adingabeen artean, Magrebetik zetozenen proportzioa hirutik bikoa izan zen, eta Sahel hegoaldeko Afrikatik zetozenena, hamarretik bi izatera pasatua zen.

${ }^{2}$ Marokotik \% 66,84, Aljeriatik \% 9,63, Gineatik \% 4,02, Boli Kostatik \% 3,24, Kamerunetik \% 0,98 eta Nigeriatik \% 0,59. ondorioz, euren integrazio- esperientzietan atzera egin dute (Senovilla, 2007).

Kolektiboaren egoera aztertzeko, Eusko Jaurlaritzaren Gizarte Bazterkeria Baliosteko Tresna Tekniko Bateratua (2019) erabili da. Fenomeno hau berria izanda, ikerketa-munduari ez dio denborarik eman kolektibo honetarako erreminta konkreturik sortzeko, baina bazterketa-egoeran (edo honen arriskuan) egonda, tresnak eskaintzen dituen kategoriak bat egiten zuten ikerketa-taldeak neurtu nahi zituen alderdiekin.

Tresna honek gizarte-bazterketako balizko egoerak baloratzeko balio du eta gizarte-bazterkeriaren egoerari buruzko gizarte-diagnostiko espezializatua egin daiteke. Horretarako, bizi-esparruka banatutako adierazle batzuk erabiltzen ditu, egoera horretan dauden eta gizarte-zerbitzuen sisteman arreta jarri behar zaien pertsonen kasuistika espezifikoa jasotzeko, bai oinarrizko gizarte-zerbitzuetatik, bai bigarren-mailako arreta-zerbitzuen ataza espezializatutik. Tresna horretan baloratzen diren bost bizi-eremuak hartuko ditugu abiapuntutzat: ekonomia, lana eta bizitegia, elkarbizitza-eremua, eremu pertsonala, osasunaren esparrua, eta azkenik, gizarteeremua. Horietan guztietan, dagozkien adierazleak ere aztertuko ditugu, ondoren profesionalek duten pertzepzioarekin alderatu ahal izateko.

Ekonomia-, lan- eta etxebizitza-esparruaren aldetik,Vinaixaren aburuz (2019), gehienek ere lanik aurkitzen ez dutenez, ez dute baliabide ekonomikorik beren garapenerako bizimodu independentea egin ahal izateko. Honen harira, Weller-ek esaten duen moduan (2007-2008), beharrezkoa da lana lortzea, batez ere lana gizarte-integrazioaren ardatza, bizitza pertsonalerako zentzu-iturria, herritarrek parte hartzeko gunea eta aurrerape nmaterialaren motorra delako.

Bizikidetza-esparruari buruz hitz egiterako orduan, aipu garrantzitsu bat da Blancas eta Jurado-k esandakoa (2010), bakarrik dauden gazte atzerritar hauek familia-sarerik ez izateak oztopatu egiten duela populazio honen gizarteratzeko prozesua, laguntza hori ez dutelako. Ondorioz, indarkeriara jo gabe, baliabide pertsonalak eta trebetasunak eskuratu behar dituzte, aurrera egin ahal izateko (Lafuente, 2010). Prozesu honetan, Manzani eta Arnoso-ren aburuz (2014) gazte hauek mezu bat jasotzen dute, beren migrazio-proiektuak derrigor osatu behar dutela, lan egiteko etorri direlako hona, nahiz eta dituzten zailtasunekin, lortzea ezinezkoa izan.

Osasunari dagokionez, jakin beharra daukagu hau prozesu ugariren sintesia dela, gorputzaren biologiarekin, inguruan dugun ingurunearekin, gizarte-harremanekin, nazioarteko politika eta ekonomiarekin gertatzen denaren artean (Alcántara, 2008; Briceño-León, 2000).

Gizarte-arloan sartzerakoan, izendatzekoa Barrón eta Sánchez Moreno-k idatzitakoa (2001). Euren esanetan, bizitzako gertaera estresagarriek zuzeneko lotura 
dute narraidura psikologikoarekin eta depresioarekin, eta, gizarte-laguntza handiagoa izanez gero, zauria murrizten da. Badirudi komunitateko beste kideekin erlazioak sortzea kontu zaila dela, izan ere, Manzani eta Arnoso-ren ideia jarraituz (2014), iritzi publikoa gero eta gogorragoa da atzerritarrekiko, eta bakarrik dauden gazte atzerritar horiei buruzko tratamendu mediatiko desegokiak, zaildu egiten du gizarteharremanak ezartzea eta haien gizarteratzea eta, ondorioz, haien ongizatea.

Tutoretzapeko gazte askok ez dute lortzen helduarorako trantsizio-prozesua arrakastaz garatzea. Langabezia- eta prekarietate-indize altuak hautematen dira, pobrezia-mailaren azpitik kokatuz (Palma-García, Ruiz Mosquera eta Vives González, 2019).

Vinaixarrek dioenez (2019), familiarengandik urrun egoteaz gain, beren zaintzaileak eta tutoretza egin dutenak ere galdu dituzte. Egoera juridiko eta administratibo berriaren ondorioz, bakarrik dauden adingabe atzerritar ohiak egoera juridiko eta administratibo berrian daude, eta, horren aurrean, hainbat arazo planteatzen dira. Arazo horien erantzunak garrantzi handia du, ez bakarrik beren bizitzarako eta etorkizunerako, baita gizartean bizitzeko ere: Non biziko dira? Nola egingo diete aurre hemendik aurrera sortuko zaizkien zailtasunei? Nola erregularizatuko ote dute Espainian duten egoera? Lan-baimena lortuko ote dute? Espainiako nazionalitatea eskuratu ahal izango dute?

Bakarrik dauden adingabe atzerritarren arestiko migrazio-fluxuak izanda, eta hauek heldutasunera ailegatzeko urteak igaro direla kontutan edukita, akademia- eta ikerkuntza-arloan oso ikerketa edota erreferentzia teoriko urriak aurkitzen dira kolektibo honen inguruan. Manzani eta Arnoso-k (2014) adierazten dutenez, kolektibo honek esplizituki adierazten dituen eskaera nagusiak etxebizitza, arlo administratibo eta judizialari dagozkionak, enplegurako prestakuntza, osasuna, aisialdia eta astialdia dira, eta erakundeen aldetik erantzunik lortzen ez badute, beren ongizate psikosoziala arriskuan jartzen da. Hori dela-eta, beharrezkoa da prozesu hau erraztuko duten estrategiak garatzea eta helduen bizitzarako gazte hauek prestatzea (Stein, 2006).

Eginkizun horri aurre egiteko, hau da, gazte hauen bizi-egoera nola hobetu helburu gisa daukaten ikerketetan aurre egiteko, artikulu honetan bakarrik dauden gazte atzerritarrekin lan egiten duten profesionalen ahotsak islatu eta aztertuko dira. Konkretuki, artikulu honen helburua profesionalen ustez bakarrik dauden adingabe atzerritarrak, bakarrik dauden gazte atzerritarrak izatera heltzen direnean, pairatzen dituzten beharrizanak identifikatzea da. Ikerketa zabalago baten parte da lan hau, Bizkaian bakarrik dauden gazte etorkinen beharrak identifikatzea helburu zuena ${ }^{3}$.

\footnotetext{
3 Deustuko Unibertsitateko "Intervención: Calidad de Vida e In-
} clusión Social” ikerketa-taldeak aurrera eramandakoa 2019. urtean

\section{Metodologia}

Helburua lortzeko, metodologia kualitatiboa erabili da, pertsonek eraikitzen dituzten iritziak, alderdi subjektiboak eta taldeen artean ematen diren harremanak ezagutzeko (Alberich, 2007). Informazioa jasotzeko erabili den erreminta elkarrizketa sakona izan da. Gidoiak, Eusko Jaurlaritzaren Gizarte Bazterkeria Baliosteko Tresna Tekniko Bateratua (2019) oinarri izanda, hamaika kategoria aztertzen zituen: 1) profesionalaren ibilbidea; 2) bakarrik dauden gazte atzerritarren hasierako ibilbidea; 3) bakarrik dauden gazte atzerritarren egungo egoera eguneroko bizitza; 4) alderdi sozialak; 5) loturak; 6) laneratzea; 7) dirusarrerak eta laguntzak; 8) erregularizazioa; 9) osasuna; 10) etorkizuneko estrategiak eta planak; 11) beharrizan nagusiak. Elkarrizketak langileen lanpostuetan burutu ziren, aldez aurretik adostuta. Solasaldiaren batez besteko iraupena ordu eta laurdenekoa izan zen. Elkarrizketa guztiak grabatu egin ziren, baita transkripzioa egin ere analisirako. Elkarrizketatu guztiek konfidentzialtasun-orria irakurri eta sinatu egin zuten, ikerketaren izaera boluntarioa helarazi eta anonimatua bermatuta.

\subsection{Parte hartzaileak}

Hamar profesionalek hartu zuten parte ikerketan. Hautatzeko irizpideak honako hauek izan ziren:

- Bakarrik dauden gazte atzerritarrekin lan egitea.

- Zerbitzu/esparru desberdinak.

- Generoa.

Ikerkuntza-taldeak zituen harremanak erabili ziren kontaktuak sortzeko. Hasieran, hamabost entitaterekin telefonoz egin zen lehenengo kontaktua; horietatik, hamarrek baiezkoa eman zuten. Horiei, posta elektroniko baten bidez informazio guztia helarazi zitzaien, elkartzeko data bat eskatzen. Hamar elkarrizketatuetatik, bostek prestakuntza- eta laneratze-zerbitzuetan lan egiten dute, eta beste bostek etxebizitza- eta aterpezerbitzuetan. Generoari dagokionez, hiru emakume eta zazpi gizon elkarrizketatu ziren (1. Taula).

zehar, BBK-k finantzatuta. Ikerketan, artikulu honetan aztertzen diren profesionalen elkarrizketekin bat, bakarrik dauden 40 gazte atzerritarrei egin zitzaien elkarrizketa. Artikulu honetan profesionalen pertzepzioak aztertzen dira Gizarte Hezkuntza graduaren gradu-amaierako lana burutzeko erraztu ziguten informazioa delako. 
1. Taula. Elkarrizketatuen profila.

\begin{tabular}{|c|c|c|c|c|}
\hline Entitatea & Emandako zerbitzua & Generoa & Identifikazioa & Data \\
\hline \multirow{5}{*}{$\begin{array}{l}\text { Prestakuntza } \\
\text { eta laneratzea }\end{array}$} & Prestakuntza eta laneratzea ardatz dituen fundazioa & Gizona & P.L.G. 1 & 2019ko azaroak 25 \\
\hline & $\begin{array}{l}\text { Lan- eta lanbide-orientazioa, prestakuntza, lan- } \\
\text { merkatura hurbiltzea eta laneratzea }\end{array}$ & Gizona & P.L.G. 2 & 2019ko azaroak 25 \\
\hline & Enplegu-orientazioa & Emakumea & P.L.E. 1 & 2020ko urtarrilak 17 \\
\hline & Prestakuntza eta ikastaroak & Gizona & P.L.G. 3 & 2019ko abenduak 3 \\
\hline & Orientazioa eta prestakuntza & Gizona & P.L.G. 4 & 2019ko abenduak 4 \\
\hline \multirow{5}{*}{$\begin{array}{l}\text { Etxebizitza eta } \\
\text { aterpetxea }\end{array}$} & Etxebizitza eta aterpetxea & Gizona & E.A.G. 1 & 2019ko abenduak 5 \\
\hline & \multirow{2}{*}{ Etxebizitza eta orientazioa } & Emakumea & E.A.E. 1 & 2019ko abenduak 5 \\
\hline & & Gizona & E.A.E. 2 & 2019ko abenduak 5 \\
\hline & \multirow{2}{*}{ Aterpetxea } & Gizona & E.A.G. 2 & 2019ko abenduak 13 \\
\hline & & Emakume & E.A.G. 3 & 2019ko abenduak 13 \\
\hline
\end{tabular}

ITURRIA: Egileen lana.

2.Taula. Analisirako sortutako kategoriak eta kodeak

\begin{tabular}{l|l}
\hline Kategoria & Kodea \\
\hline Ekonomia-, lan- eta etxebizitza-esparrua & $\begin{array}{l}\text { - Egoera ekonomikoa. } \\
\text { - Ean-egoera. }\end{array}$ \\
\hline Bizikidetza-esparruatza-egoera. & $\begin{array}{l}\text { - Harreman eta lotura afektiboak izatea } \\
\text { - Elkarbizitzarako laguntza soziala jasotzea. }\end{array}$ \\
\hline Esparru pertsonala & $\begin{array}{l}\text { - Konpetentzia eta gaitasun pertsonalak. } \\
\text { Kanpoko egoera. } \\
\text { Bizi-dinamismoak. }\end{array}$ \\
\hline Osasunaren esparrua & $\begin{array}{l}\bullet \text { Osasun-egoera orokorra. } \\
\text { - Gainerakoak. }\end{array}$ \\
\hline Gizarte-esparrua & $\begin{array}{l}\bullet \text { Onarpen soziala eta bizikidetza komunitarioa. } \\
\bullet \text { Gizarte-ingurunearekiko harremana. }\end{array}$ \\
\hline
\end{tabular}

ITURRIA: Egileen lana.

\subsection{Datuen analisia}

Elkarrizketen analisia egiteko, kategorizazio-, kodifikazio- eta birkodifikazio-fase desberdinak burutu ziren. Eusko Jaurlaritzaren Gizarte Bazterkeria Baliosteko Tresna Tekniko Bateratua oinarri izanda, analisi iteratiboa egin zen, azkeneko "inter-epaile" egiaztatzearekin, azkeneko kategoriak eta kodeak zehazteko eta balioztatzeko erabili izan zena ( 2 . Taula).

\section{Emaitzak}

Atal honetan, elkarrizketetatik ateratako emaitzak helaraziko dira, Eusko Jaurlaritzako bazterketa tresnan agertzen diren kategoriak errespetatzen: 1) ekonomia-, lan- eta etxebizitza-esparrua; 2) bizikidetza-esparrua; 3) esparru pertsonala; 4) osasunaren esparrua; eta 5) gizarte-esparrua.

\subsection{Ekonomia-, lan- eta etxebizitza-esparrua}

Kategoria honetan, bi azpipuntu identifikatu ditugu: egoera ekonomikoa eta lan-egoera, eta etxebizitza-egoera.

\subsubsection{Egoera ekonomikoa eta lan-egoera}

Egoera ekonomikoari buruz, elkarrizketatu gehienek uste dute adingabeentzako etxe batean 18 urte bete arte egon badira, dirulaguntzak izapidetzeko laguntza jaso ohi dutela. Pertsona horrek 340 euro jaso ahal izango ditu 30 hilabetez, eta 21etik 23ra dirusarrerak bermatzeko errenta (DBE) jaso ahal izango du. Baina zer gertatzen da gainerako kasuetan, hau da, 23 urtera arte? Zertaz hornitzen dira? Hori da elkarrizketa guztietan egiten den galdera orokorra. Baina pertsona horiek adingabeentzako etxe batean egon ezean, ezin izango dute laguntzarik izan ezer eskatzeko:

Batzuek Bilbotik kanpo etxebizitzak lortzen dituzte, baina ezin dituzte garraioa, janaria edota arropa ordaindu. Batzuetan ez ditu behar guztiak betetzen. (P.L.G.2)

340 euro kobratzen dituzten pertsonen artean, logela bakoitzeko 200 euro ordaintzen dute normalean, eta bizitzeko 140 eurorekin geratzen dira; dela jakietarako, dela garraiorako. Baina askotan hori ez zaie iristen beren beharrak asetzeko. Elkarrizketatu batek adierazi zuenez, elkarrekin bizi dira maiz, baina ez desio propioz, premiagatik baizik. Batzuek 
pribilegioa moduan, fundazioren baten laguntza daukate, baita diru pixka bat lortzeko aukera erakundeekin lankidetzan jardunda. Gazte horietako askok dirua lortzen dute lagunei mesedeak edo lanen bat eginda. Edo langabezia-egoerak ere aipatu izan zituzten. Egoera honek baliabide-gabezia dakar, bizimodu independente bat izateko eta garapen bat izateko prozesua zailtzen. Ondorioa, kalean bizitzea izan ohi da, eta askotan, delitu egiten bizirik irauteko.

Laburbilduz, egoera horretan dauden gazteek, adingabeentzako etxe batetik etorri badira, errazago izango dute dokumentazioa lortzea; prozesua ondo egin badute, behintzat. Hala ere, zaila izango da, dirusarrerak oso eskasak baitira. Prozesua ondo jarraitu ezean edo ailegatzean dagoeneko 18 urte izanez gero, ez daukate aukerarik dirulaguntzarik jasotzeko. Gaztea izatea gaur egun zaila da ekonomikoki bakarrik bizi ahal izateko, are gehiago etorkina izanda eta dokumentaziorik gabea:

Gazte batzuk 18 urterekin ateratzen dira, sarrerabaimena gabe, erreferentzizko koordinatzaile gabe, dagokion prestazioa edo zentro gabe, eta kaleko egoerara pasatzen dira. Hemen, paperen arretarako erraztasunik ez badago, horrela da. (P.L.G. 4)

Lan-egoerari buruz hitz egiterakoan, hainbat gauza komentatzen dituzte, batez ere erregularizatzeko lana lortzearen garrantzia. Orokorrean, prozesu berbera komentatu ohi dute elkarrizketatu guztiek: haien ibilbidean dena ondo badoa, izenemandako kurtsoetara joan eta bigarren urtean praktikak egiten badituzte, etorkizunean lan egin ahal duten enpresa batera eramaten dituzte. Hori baino lehen, eskolagraduatua premiako dute, erdi-mailako ikasketak egin ahal izateko. Ikasle batzuk hirugarren sektoreko proiektu batzuetan parte hartuta, laneratzea lortu izan dute.

Ez dago bizitegi-egonkortasunik, eta, hori gabe, oso zaila da prozesu egonkor batzuk izatea, prestakuntza-prozesu batzuk, etxebizitzabilaketa bat... garrantzitsuena ez baitago estalita; gero, prestakuntza izango litzateke, hau da, prestakuntzetara iritsi ahal izatea. (P.L.E. 2)

Elkarrizketa guztietan aipatzen da kolektibo honek laneratzeko izaten duen zailtasuna, gazte horiek lan-katean azkenak baitira, hau da, kontratatzen dituzten azkenak izango dira, inguruan duten estigmaren ondorioz. Badaude batzuk aurretik praktikak eginda, lan egiteko aukera izan dutenak; eta horren bitartez erregularizazioa lortu dutenak. Hori ez da bakarrik haientzat ona ekonomiaren aldetik, baita erantzunkizunagatik ere, baliagarri sentitzearekin eta haien bizitzaren helburuari erantzutearekin zerikusia daukalako. Weller-ek (20072008) aipatzen duen moduan, beharrezkoa da lana lortzea, batez ere lana gizarte-integrazioaren ardatza, bizitza pertsonalerako zentzu-iturria, herritarrek parte hartzeko gunea eta aurrerapen materialaren motorra delako. Beste datu interesgarri bat, gai honi buruzkoa, Espainiara heldu aurretik gehienek, lanesperientziak izan dituztela Tangerren, dirua lortzeko eta hona heldu ahal izateko. Behin lana lortuta ondo begiratu behar da zein egoeratan lan egiten ari diren: normalean ustiapen-egoeretan, lan oso prekarioetan eta baldintza latzgarrietan:

Begira zer lan-egoeratan dauden: esplotazioegoeretan, megaprekario-lanetan, baldintza ikaragarrietan. Hori hobeto iruditzen zaigu lanik ez egitea baino? Lan-merkatuan inbertitzen duten bitartean, berdin zaigu nola txertatzen diren. (E.A.G. 2)

\subsubsection{Etxebizitza-egoera}

Etxebizitzaren egoerari buruz hitz egiten dugunean, profesional gehienek, babes-zerbitzuetara hurbiltzen direla aipatzen dute, bizi eta lo egiteko lekua behar dutelako. Babes-zerbitzuek baliabide urriak dituztenez, askok kalean bizi eta lo egiten dute. Kasu batzuetan, zortea izanez gero, zenbait erakundezerbitzuez aprobetxatu ahal dira. Elkarrizketa guztietan aipatzen da erakunde askotan lan handia egiten dela pertsona hauei bizitza duin bat emateko, honako hauek aipatuz: Ellakuriako Gauean, Harribideko Gauean, Adsiseko edo Peñascaleko pisu batzuk..., baita Hemen elkartea aipatu zen, gazteei tramite burokratiko guztiekin laguntzen dietelako. Oso garrantzitsuak dira zerbitzu hauek hainbat eginkizunetan akonpainamendua ematen dutelako: errolda tramitatzen laguntzen die gazte hauei, pasaportea eskatzen (normalean lortzeko hiru edo lau hilabete itxaron behar dena), eta erresidentziabaimena tramitatzen diete, logela bat alokatu ahal izateko:

Hasiera batean, aterpetxearekin sarea izan dezaten saiatzen gara, gizarteratzeko laguntza izapidetzen ari garen bitartean; gero, Cear etxeak plaza batzuk ditu bere pisuetako batean, eta hori ere erabiltzen dugu; eta partzuergoko erakundeak ere erabiltzen ditugu, edozer dela ere, Gauean Ellakuria, Gauean Harribide, Adsis edo Peñascaleko etxebizitzak. (E.A.E. 1)

Askotan gertatu izan da, nahiz eta adingabeen pisuetan egon izan eta pasaportea edukita ere, ez dutela erresidentzia-baimena lortu, eta ia urtebete adingabeko pisuetan erroldatuta egotera heldu direla, nahiz eta han ez bizi. Haien egoera erregularizatzea profesional guztien iritziz erronka handienetako bat da. Aipatu beharrekoa da diputazioak adinez nagusi direnen 32 lagunentzako zentro bat daukala, non haien egunerokotasunaz eta haien paperen erregularizazioan laguntzen dieten. Zerbitzu honek ezin duenez kolektibo osoari erantzuna eman, lehen aipatutako zerbitzuak gainerako gazteei heltzen saiatzen dira, gehienak Bilboko Gizarte Larrialdietarako Udal Zerbitzuaren ${ }^{4}$

${ }^{4}$ SMUS gaztelaniazko sigletan. 
eskumena dena (etxe gabetasun-egoeran dauden pertsonentzako udal zerbitzua).

Normalean, adingabeen zentrotik irten eta ostaturik ez dutenean (ohikoa izaten da), Gizarte Larrialdietarako Udal Zerbitzura joaten dira, eta hortik plaza duten aterpetxeetara bideratzen dituzte... (E.A.G. 1)

Prozesu honetan arazoren bat izan badute, edo aurretik aipatutako zerbitzuak jasotzerik izan ezean, bitartean kalean bizi behar dute, eta San Mames edo Rekaldeko inguruetan bizi izaten dira. Okupatutako lekuak eta asentamenduak ere sortu dituzte behar horiek asetzeko. Instituzioek ez dute inoiz hitz egiten asentamendu hauei buruz, baina nahikotxo daude; gainera, denboran zehar luzaro mantendu direnak. Elkarrizketatuen esanetan, noizbehinka poliziak edo garbiketa-taldeek suntsitzen dizkiete; askotan zerbitzu sozialei deitu gabe. Kaleratze askotan, ez zaie pertsona hauei abisatzen eta dena botatzen dute, adibidez paper garrantzitsuak, txosten medikuak, dokumentazioa... 1978ko Konstituzioan, 47. artikuluaren esana hurratuz.

\subsection{Bizikidetza-esparrua: Harreman eta lotura afektiboak izatea eta elkarbizitzarako laguntza soziala jasotzea}

Zerbitzuetan, hezitzaileek bakarrik dauden gazte atzerritarrekin harremanak eta loturak sortzen dituzte, eta bizitzan erabakiak hartzen laguntzen dizkiete. Akonpainamendua egiteaz gain, langileen irudia oso garrantzitsua da gazte askorentzako.

Erreferentzia irudi hau izateari esker, asko ezagutzen dute haien harremanei buruz. Kasu batzuetan, haien artean harremana ez da ona, batez ere kalean bizi direnen artean, ez dira bata besteaz fidatzen. Aipagarria da, Saharaz hegoaldekoen artean harremana estuagoa dela; herrikideak direnez, haien artean laguntzen dira, magrebtarrak aldiz, modu independenteagoan joaten dira, bakoitza bere bidea egiten:

Kaleak suntsitzen du. Etxegabetasun sakonenean sartzeko orduan galtzen diren harremanak bezain garrantzitsuak dira egoera horretatik ateratzeko sortzen diren harremanak. (P.L.G. 2)

Askotan, zerbitzuetara sartu baino lehen ez dute laguntza-sarerik, eta zerbitzuetara sartzerakoan, babesa sentitzen duten lehenengo aldia da. Kontuan izan behar dugu Blancas eta Juradok aipatzen duten moduan (2010), familia-sarerik ez izateak oztopatu egiten duela populazio horren gizarteratze- prozesua. Batzuetan, oso erlazio onak sortzen dira zerbitzuen partaideen artean, oso aldaketa handia izanik, normalean sare oso txiki batekin heltzen direlako, eta gehienetan haien ezagunak egondako aurreko zerbitzuan ezagututakoak direlako. Batzuetan ere, ezagunen bat daukate haien jatorrizko herrialdetik etorritakoa:
Gehienek oso sare txikia dute. Ea, bada, jatorrizko herrialdeko jende askok badu ezagunen bat; gero, ikastaroko beste ikaskide batzuk; ireki dakiokeen beste adar bat programako ikaskideak dira. (E.A.G. 3)

Elkarrizketa guztietan zehar, askotan aipatzen da haien jatorrizko familiaren kontua.

Askotan nahiago dute senideei ez deitzea haiek ez kezkatzeko, baina egia da, nolabait, telefonoz harremanetan daudela. Kalean dauden pertsona askorentzat garrantzitsuagoa da familiarekin bi egunetik behin komunikatzea, gauetarako bakarrik lo egiteko sabaia edukitzea baino. Beraientzat garrantzitsuena amarekin hitz egitea eta ondo daudela esatea da; gezurra izanda ere.

\subsection{Esparru pertsonala}

Kategoria honetan, hiru azpipuntu aztertuko ditugu: konpetentzia eta gaitasun pertsonalak, kanpoko egoera, eta bizitzaren dinamismoak.

\subsubsection{Konpetentzia eta gaitasun pertsonalak}

Haien gaitasunak harremanetan jartzeko orduan ikastaroetako irakasleekin sortutako loturarekin erakusten da. Aldiz, batzuetan, portaera txarra izaten dute profesionalekin. Arazo hau erreferente heldurik ez izateagatik izan daiteke eta Lafuentek (2010) esaten duen moduan, indarkeriara jo gabe egoera zailei aurre egiteko baliabide pertsonalak eta trebetasunak eskuratu behar dituzte gazteek, komunikazio-trebetasunak ikasiz eta emozioak eta sentimenduak adieraziz, eta hori erreferentziazko heldu bat eduki ez bada zaila gerta ohi da. Baina gehienetan, pisu batean hartzen zaienean, denak dira gai elkarrekin bizitzeko, ikasteko, janaria prestatzeko, garbitzeko txandak kudeatzeko... Elkarrizketa gehienetan komentatzen da gazteak direla, freskotasuna eta egokitzeko gaitasun handia dutenak, jatorriz dituzten gaitasun asko baitituzte eta bidaiak berak ematen dizkien beste gaitasun batzuekin datozelako, baina batez ere balio handiko gauza batekin datozelako: erresilientzia:

Serieko gaitasun askorekin datoz, baina baita bidaiak berak ematen dizkien beste batzuekin ere, eta horiek ere asko dira balio gisa berreskuratu daitezkeenak. (P.L.G. 4)

Gizarte-gaitasunei buruz hitz egiterakoan, beren esperientzia kontatzeko eskaintzen dira beste batzuei akonpainamendua egiten laguntzeko, eta hau baloratu beharreko beste gauza bat da, puntu honetara heldu diren gazteak, prozesu honen azkenengo etapan daudelako eta haien energia etorri berri diren gazteei laguntzeko balio duelako.

Hezkuntza eta prestakuntzari buruz hitz egiterakoan, hainbat gai atera ziren elkarrizketetan. Elkarrizketatu guztien aburuz, batzuetan ez dute lan bat aurkitzeko behar diren oinarrizko gaitasunik (nola sortu Gmail- 
eko kontu bat adibidez), teknologiarekin trebeziarik ez dutelako. Baina beste gutxi batzuk, aldiz, Interneten sartzen dira joaten diren zerbitzuetako ordenagailuetan eta nolabaiteko trebezia dute teknologian. Ikasketei buruz hitz egiterakoan, batzuk batxilergoko mailarekin iritsi direla esaten dute, lehen-mailako ikasketekin eta alfabetizatuta, eta haien hizkuntzaz gain, zenbait hizkuntza hitz egiten dituzte: arabiera, bereberra, batzuk frantsesa ere, eta oso maila ona daukate.

Gainera, batzuek igeltseroak direla esan dute, mekanikari, soldatzaileak, hau da, lehen-mailako prestakuntza dutenak. Beste erakunde batzuetan ere batzuek bigarren-mailako ikasketak amaitu gabe dituztela esan dute, baina horien barruan aniztasun handia dago; gehienek bigarren-mailako ikasketak baitituzte. Unibertsitate-ikasketak hasita dituen kasuren bat badago. Jende oso motibatua dago, gehiago ikasi eta etorkizun hobea bilatu nahi duena. Marokon ikasketak dituen eta homologatu nahi duen jende asko dago; eta batzuetan lortu egiten dute:

Bateren bat batxilergoarekin iritsi ahal izan da hona, baina oso gutxi etorri dira prestakuntza horrekin, gehienekin, lehen mailako ikasketekin. (E.A.G.3)

Baina, batez ere, praktikak dituzten prestakuntzak egin nahi dituzte, denborarekin, lan-eskaintza bat lortzeko aukera izan dezaten. Nahia honek Nazioarteko elkarteek aldarrikatzen duten ideia gogoarazten du, hots, hezkuntzaren zeregina ez dela bakarrik jakintzen helaraztea, baizik eta lanmundurako beharrezko gaitasun guztiak eskaintzea, sektore horien prestakuntza-beharrei erantzuteko eta herritartasuna (modu klasikoan ulertuta) jarduteko eskubidea ziurtatzeko (Unesco, 2020). Honen harira, kolektibo honen erronkarik handienetariko bat hezkuntza da. Oro har, gaztelania ikastea lehentasunezkotzat jotzen da elkarrizketa guztietan. Hizkuntza eskuratzea oso garrantzitsua da beste etapa batera igarotzeko:

Hizkuntza funtsezkoa da, hori baita lan-esparru horretara eramateko dugun modua. Ezin dena zera da, enpresa batera ailegatzea, eta ez dezatela agindu bat bereizten jakin eta ez dezatela hitz egin. (P.L.G. 1)

Oso garrantzitsua da lana aurkitzean hizkuntza jakitea. Askotan, hemen denbora asko eraman arren, gaztelania-maila oso baxua dute. Erakunde batzuetan ikastaro praktikoak koordinatzen dituzte baina, hala ere, gaztelaniako eskolak eskaintzen dituzten zerbitzuak urri dira dagoen eskaerarako.

\subsubsection{Kanpoko egoera}

Prestakuntza-gaietan ohikoena da, adibidez, goizean edo arratsaldean ikastaro bat egitea, LHkoa edo erdi-mailakoa. Gero, prestatu ere egiten dira, gaztelaniarekin edo ikastaroekin, DBH lortu ahal izateko. Eta hortik, Lanbide Heziketa egin badute, erdi-mailako gradua egin dezakete. Pixkanaka erabakitzen dute haien ibilbidea, indibidualizatua izanik. Prestakuntza-aukera zabala da eta elkarrizketa guztietan argitzen da:

Normalean bigarren urtean praktikak egiten dituzte eta etorkizunean kontratatu ditzaketen enpresetara bidaltzen dituzte, ondoren kontratu bat izateko; eta ez badoa, lan bila jarraituko dute edo Lanbideren beste ikastaro batzuk edo beste elkarte batzuen bidez egitea gomendatzen diete. (P.L.G. 2)

Erakundeen aldetik inplikazio handia dago, gainera, formazio eta prestakuntza gehiago egoteko, aurrera jarraitzea aldezten dute. Hor ikus daiteke prestakuntza-sistemaren neurrian, gazte gehienek lan-sare eta lan-alderdi berberetan egongo direla. Hala ere erakundeen aldetik, beste aukera mota batzuk eskaintzen saiatzen dira.

\subsubsection{Bizi-dinamismoak}

Bizi dinamikei buruz hitz egiterakoan, migrazioprozesua izan da ateratako gairik errepikatuena. Askotan, gazteek duten bizitza-proiektua edo migrazio-proiektua ez da berea, normalean familiek erabakitzen dute hau egitea eta dirua inbertitzen dute horretan. Bere adineko pertsona askok bezala, ez dute oso argi bere profesionaltasun-esparrua, horregatik, oso ikastaro desberdinetan egoten dira. Gehienek geratzeko asmoa dute, gainerakoak joaten badira Bartzelonan familia dutelako eta hara joan nahi dutelako da:

Migrazio-proiektu horretan, bizi-proiektuak daude, emantzipazio-prozesu bat dago. Bizibidea bakoitzarena da, migrazio-proiektuak zailtasunak ditu. (P.L.G. 4)

Askok argi dute hona lan egitera datozela, eta egiten duten lehen gauza prestakuntza jasotzea da. Hasieran lortzeko oso zailak diren itxaropenak dituzte, ez dutelako errealismorik. Sufritu egiten dute errealitatea ikustean eta zein zaila izango zaien helburu horiek lortzea. Lan egin dezaketen lekuan geratzeko asmoa dute eta, ondorioz, paperak lortu nahi dituzte. Beren herrialdeetatik datoz eta lana izateko baimenak izan nahi dituzte, baina migrazioproiektu honek zailtasun handiak ditu. Ez dute modu egonkorrean bueltatu nahi, ideia hori baztertuta dago. Gehienez ere, Frantziara edo Europako beste herrialde batzuetara joatea dute buruan baina oso kasu gutxi dira, oro har. Hemen geratu nahi den jendea da, hemen bizi-proiektu bat egin nahi duena:

Azkenean, beraientzako prozesu bat dela uste dut, hain zaila eta luzea, ezen beste herrialde batean antzeko prozesu bat berriz ez hasteagatik geratzea erabakitzen baitute. (P.L.E. 2)

Askotan egoera gogor honek hainbat bide jarraitzea ekartzen du. Elkarrizketetan bi adibide esanguratsu 
antzeman dira. Lehenengoa, haien jatorrizko erlijiora gehiago hurbiltzea da. Askotan, erlijio-mailako kide izatearen sentimendua sortzen dute; Ramadanaren gaia eginez, arkumearen eguna, edozein haragi ez jatea eta gauza horiei eusten direnak asko dira, nahiz eta beren herrialdean ez praktikatu, hemen inor sentitzen direnez honekin identifikatuta sentitzen dira. Eta beste adibidea, zelan mantentzen duten haien duintasuna da. Ikusten da zelan ikastaroetara doazen neska-mutilak oso dotore joaten direla, nahiz eta leku oso txarretan lo egin. Irudi bat mantentzen saiatzen dira, bere buruarentzat, eta are gehiago, besteentzat.

Duintasunaz hitz egingo nuke, ikusten ditudalako ikastaroetara doazen neska-mutilak, leku batzuetan lo egiten dutenak eta leku horietatik pintzel bat eginda irteten direnak. Mutiko hauek irudi bat mantentzen saiatzen dira, beren buruarentzat ere bai, ez besteentzat hainbeste, "Duintasuna mantendu nahi dut lo egiten dudan tokian, edonon izanda ere”. (E.A.G. 2)

\subsection{Osasunaren esparrua}

Osasun arloan hainbat alderdi aipatu ditzakegu, haien artean osasun fisikoarena, kalean egotearen tentsioak eta baliabide ezak kalte fisikoa eragiten baitu. Osasun zerbitzua bermatu gabeko eskubideetako bat da, inork ez die laguntzen erroldaprozesuan eta ez dute erraz Atzerritar Nortasunaagiria 5 lortzea. Bilboko Udalak, besteak beste, eskaintzen dituen zerbitzu urriek ere eragin handia dute prozesu honetan:

Eskubideak galtzen joaten dira [...] adibidez, Atzerritar Nortasun-agiria ezin zuten eduki, ez baitzegoen inor prozesu horretan edo erroldan laguntzeko. (P.L.G. 1)

Askotan, hiru aterpe-egun ematen dizkiete, eta hiru hilabete itxaron behar izaten dute berriz aukera hori izateko; gauza bera gertatzen da jangelekin eta dutxekin, eta honek ondorio fisikoa dakar. Muskuluetan kalteak izaten dituzte kalean lo egitean, bizkarreko mina eta loaldiko gaitzak, besteak beste.

Oro har, oso osasuntsuak dira, ohitura gutxi dute medikura joateko eta joatean hepatitisa bezalako gaixotasun kronikoen berri izaten dute. Osasunzerbitzuek ez dute haien babesa bermatzen; askotan, gaixotasun larriren bat edo osasun-arazoren bat badute, ezin diote ekonomikoki aurre egin. Gainera, elikadura eta higiene faltagatik, ahoarekin arazoak daudela aipatu da. Baina, elkarrizketatuen arabera,orokorrean gazteen osasun fisikoa ona da, ez dago ezer esanguratsurik bakoitzak izan dezakeenaz harago:

Oro har, oso osasuntsuak dira, eta ez dute medikuarenera joateko ohitura handirik. Orduan,

\footnotetext{
${ }^{5}$ TIE gaztelaniazko sigletan.
}

askotan joaten direnean jakiten dituzte gaixotasun kronikoak dituztela, hala nola hepatitisa. (E.A.G. 3)

Adimen osasunari buruz hitz egiterakoan, kalean egoteak ondorio psikologiko sakonak dituela aipatzen da, eta hauek ezin dira balioetsi. Zenbait neska-mutilek laguntza psikologikoa behar dute, kanpoko presioen eta auto presioaren erruz, psikologikoki bizi-proiektuak oso zama handia baitu. Zama oso garrantzitsuak dituzte, bizi-historio kaltetsuak eta sendatu gabeko emozioak edo ondo eraiki gabeko elementu edo alderdiak eta askotan ez dute honi aurre egiteko modu egokirik aurkitzen:

Zailtasun gehiago ikusten ditugu maila psikologikoan, maila mentalean. Azkenean, neska-mutil horiek oso prozesu gogorra igaro dute, eta bazterketa-egoeretan egoteak, emozio mailan, gaizki egotea eragiten du. (P.L.G. 1)

Adimen osasunaren inguruan, elkarrizketa batean, kasu oso zailak aurkitu dituztela komentatzen da, haien artean psikosia garatu duen mutil batena, kultura eta egoera honetara moldatu ezinagatik. Normalean diagnostikoa izaten da arazoa, baina arreta-larrialdietarako ezarritako sistemen barruan, buruko gaixotasunen bat badago, nahiz eta osasuntxartelik ez izan, edozein osasun-zerbitzutatik hartzen zaie. Arazoa diagnostiko hori da, denbora behar delako ondo egiteko.

Alde beretik doan beste gai bat, mendetasun eta droga-mendekotasunen gaia da. Egia da, halaber, osasun mentaleko kasu oso puntualak edo drogakasuak daudela, disolbatzaile-gaiak, haurrak hondatzen dituzten gaiak, eta beherantz joateko errutina batean erorarazten dituztenak, gorantz joan beharrean. Markez eta Pastorrek (2009) esaten duten moduan, migrazio-proiektuaren porrotarekin eta haren bizi-egoeraren inguruabar larriekin zuzenean lotutako alderdia da.

Ez da orokortua, [...] kasu oso puntualak izaten dira, haxixa edo alkohola kontsumoa egon daiteke une jakin batean, baina ikusten den guztietan, interbentzioaren intentsitatea igotzen saiatzen gara. (E.A.E. 1)

Gazteen zati txiki batek kontsumitzen du eta beste zati handi batek ez, baina kontsumo horiek kaleko bizipena zein gogorra den aldetik sortzen dira. Erlijioa dela eta, ez dago oso ondo ikusia alkohola edatea, kontsumoa murriztuz. Baina, maila ekonomikoagatik ere, drogak hartzea zaila da. Kostuarekin arazoak dituzten eta ludopatiarekin ere arazoak dituzten neska-mutilen kasuak ikusi ahal izan dira:

Disolbatzailearen edo itsasgarriaren kasuan, oso kasu gutxi ezagutu ditugu, eta oso hautsita zeuden neska-mutilak ziren, hau da, emozio mailan oso gaizki zeudenak. (P.L.E. 2)

Adingabeentzako zentroetatik irtetean, ez dira gai kalean egoteko eta ondorioz kolaren kontsumoak 
izan dituzten eta disolbatzaileekin arazoak izan dituzten taldeak egon dira denboraldi batean, elkarrizketa batean komentatutakoaren arabera. Aldiz, alkoholaren kontsumoa erlatiboa da. Batzuek, beste edozein gaztek bezala, parrandan ibiltzea eskatzen dute. Egia da mugikorrarekin apustujokoren bat gertatu dela. Kontsumoak eragin garrantzitsua du egoera emozionalean, osasuna eta talde-dinamikak kaltetzen duelako.

\subsection{Gizarte esparrua}

Kategoria honetan, hiru azpipuntu identifikatu ditugu: onarpen soziala eta bizikidetza komunitarioa, gizarte-ingurunearekiko harremana, eta gizartean parte-hartzea.

\subsubsection{Onarpen soziala eta bizikidetza komunitarioa}

Jadanik, orokorrean bizirauteko behar diren gaiak aipatu eta gero, egunerokotasunaren eta onarpen sozialaren eta bizikidetza komunitariorena egoera komentatuko dugu. Horien artean, gremio-mailan, berebereak taldetan batzen dira eta haien artean ezagutzen dira. Gehiago elkartzen dira, landaeremukoak direlako, eta komunitate-lotura handiak dutelako. Egia da zentro batzuetan, norbait osasunegoera txarrean edo gaizki badago, haien artean zaintzeko beharra hautematen dutela; baina ezin da orokortu, kalean talde oso zabalak bait daude:

Berbereak agian, apur bat elkartuago baitaude eta euren artean elkar ezagutu eta elkartzen baitira. Eta, nire ustez, are gehiago, landa-eremukoak dira gehienak, eta askok lotura komunitario handia dute euren artean. (P.L.G. 1)

Migrazioa trantsizioa eta bidaia hain gogorra eta zaila denez, haien herrikideekin eta berdinekin elkartzeko joera dute, azkenean, nahi duten gauza bakarra gehiago konektatzea eta bat egitea da. Gazteekin eta erreferenteak diren pertsona helduekin, aisialdi-sareak sortzea da profesionalen helburua arlo honetan. Egunez egun, haien artean ere, lagun-sareak egiten dituzte, jakina, ikastetxean elkar ezagutzen dutelako eta elkarrekin bizi direlako. Askotan oso osasuntsua izaten dira erlazio hauek, elkarri laguntzen diotelako:

Aisia sarea egin dezaten saiatzen gara, gazteekin eta erreferenteak diren helduekin. Eguneroko bizitzan, lagun sarea ere egiten dute. (E.A.E. 1)

\subsubsection{Gizarte-ingurunearekiko harremana}

Errealitate horretan lurreratzea, eta elkarrekin ondo bizitzen ikastea, hiru bat urte kostatzen zaie, ingurunera moldatzen diren arte. Esan genezake faktore hori, hizkuntzaren ondorioagatik dela, eta hemengo jendearekin harremanak izateko premia handia dutela. Baina, oso zaila daukate harremanak izatea, askotan atzerritarrak izateagatik baztertzen dietelako:

Alde batetik, harro daude euren jatorriaz, euren herriaz, baina gero ez zaie gustatzen mutil marokoarrekin harremanak izatea; izan ere, azkenean, oso estigmatizatuta dagoen kolektibo bat da, delinkuentziarekin oso lotuta dagoena. (P.L.E. 2)

Hala ere, elkarrizketa batzuetan aipatzen da, adin txikikoa izanda (18 urte izateko prozesuan) hemengo neska-lagunak dituztela eta ez dituztela arazorik izaten.

\subsubsection{Gizartean parte hartzea}

Elkarte askok hainbat ideia dituzte haien gizarteratzea errazteko. Kide izateko eta parte hartzeko gonbidapenak jasotzen dituzte gazte gunetik eta Scout taldeetatik, parte hartzeko espazioak helaraziz. Gainera, auto babeserako eskubide eta betebeharrei buruzko ikastaroak dituzte, galdera hauek eginez: zer esan nahi du herritar izateak? zer egiten da estereotipoa legitimatzen denean, eta zer egin daiteke aldatzeko? eta zer egin daiteke elkarrekin bizirauteko? Garrantzitsua da komunitate-euskarriko proiektuak sortzea, pertsona horiek komunitate-alderdian inbertitu ahal izateko. Hala ere, uste da ez daudela proiektu nahiko ildo honetatik doazenak.

Parte izan eta parte hartu behar du. Zentzu horretan, parte hartzeko guneak ahalbidentzen ditugu, haiek zerbait ematen dutela senti dezaten, jasotzeaz gain. (P.L.G. 3)

\section{Eztabaida eta ondorioak}

Ikerketan zehar egiaztatu ahal izan dugunez, bakarrik dauden gazte atzerritarren egoera ez da erraza. Honetaz gain elkarrizketetan zehar aipatzeko beste gai desberdin atera genituen, laguntzen gaituela bakarrik dauden gazte atzerritarren egoera gogorra ulertzen.

Lehenik eta behin, erregularizazioari dagokionez, kudeaketa administratibo txarra azpimarratu behar da; izan ere, bizileku- eta lan-baimena lortzea utopikoa da gazte horientzat, nahiz eta hori funtsezkoa izan gainerako eremuak hobetzeko. Ekonomiaren, lanaren eta bizitegien esparruari dagokionez, ikusi dugu zailtasun nagusiak administrazio-erregularizaziorik ezaren ondorio direla, egoerak ez baitie uzten duintasunez lan egiten, eta, hartara, independentzia ekonomikoa lortzen, haiek babesten dituzten baliabide edo erakundeetatik urruntzeko. Vinaixarrek (2019) aipatutako egoerak gogoarazten du elkarrizketatuen testigantza: gehienak langabezian daudela, errekurtso faltarekin eta, hori dela eta, kalean bizi direla, askotan, delituak egiten behartuta bizirik 
irauteko. Baliabide ekonomiko gutxi dituztenez, benetan zaila da norberaren etxebizitza eskuratzea (logela bat alokatzea, pisu bat alokatzea, etab.). Gainera, egoera administratibo horren eta egoitza-baldintzen ondorioz, oso zaila da bakarrik dauden gazte atzerritarren independentzia bultza lezaketen gizarte-laguntzak eskuratzea. Sistemaren akats horien guztien ondorioz, bakarrik dauden gazte atzerritarren ongizatearen erantzukizuna gizarteratze-arloan lan egiten duten erakundeena da, eta, profesionalen bidez egiaztatu ahal izan dugunez, bakarrik dauden gazte atzerritar gehiago daude baliabideak baino. Beraz, ezin zaie guztiei erantzun, eta horietako askori gizarte-bazterketako egoera osoan uzten zaie. Egunero haiekin lan egiten duten profesionalen ekarpenen arabera, esan dezakegu gazteek ez dutela itxaropena guztiz galdu eta ingurune soziokulturalera egokitzeko ahaleginak egiten jarraitzen dutela, baina kolektiboaren estigmak eta gizartean garatzen joan diren estereotipoek asko zailtzen diete gizarteratzea, eta, ondorioz, garapen pertsonalerako aukerak murrizten dituzte. Aipagarria da, halaber, bakarrik zeuden gazte atzerritar gehienak adingabeak zirela Espainiara iritsi zirenean, eta erakunde eta instituzioetatik kanpo ez dutela erreferente egonkorrik izan helduarora igarotzeko prozesuan laguntzeko. Hori dela eta, ez dute komunikatzeko, prestatzeko eta abarretarako gaitasunik, nahiz eta ikasteko eta prestatzeko gai direla frogatu. Ildo horretatik, esan behar da Espainian aurkitu den errealitatea ez datorrela bat migratu aurretik diseinatu zituzten helburuekin edo planarekin; izan ere, migrazioa iristean eta lanean hastean oinarritzen zen, baina ez da iristean aurkitzen dutena, gizarte-baliabideekin lotutako prestakuntza-prozesu luzeei aurre egin behar baitiete, eta, beraz, desoreka psikologiko handia dago. Manzani eta Arnosok (2014) aipatzen duten arriskua agertzen da: gazte hauek ezin dutela integrazio-prozesu egoki bat lortu, beren migrazioproiektuak modu egoki batean lortu ez dutelako eta euren bizitza zailtasunez beterik dagoelako.

Osasun-arloarekin jarraituz, oro har, migrazioprozesua hastean osasun fisiko ona duten mutilak dira, baina bidaia aurrera egin ahala, okerrera doa bizi diren baldintzen ondorioz, hala nola etxebizitzaren egoera txarra, kale-egoerak, oinarrizko beharretarako estaldurarik eza eta abar. Nabarmendu behar dena dauzkaten arazo psikologikoak dira. Gainera, helmugako herrialdera iristean pairatzen duten bazterketa eta marjinazioak areagotu egiten du egonezina, babesik eza eta bakardadea. Elkarrizketetatik egiaztatu ahal izan da badaudela buru-nahaste larriak izaten dituzten gazteak, eta, nahiz eta urriak izan, hauei adi egon behar garela. Herrialde hartzailean ez da droga-kontsumorik gertatzen kasu gehienetan, eta gertatzen bada, maiztasun txikikoak dira eta, oro har, ez dira drogamendekotasun larriak izaten. Hala ere, azpimarratu behar da askok behin eta berriz kontsumitu dituztela arnasteko substantziak, errealitatetik ihes egiteko. Egoera hori ikusten da helmugako herrialdean, gazteak etxegabe daudenean, baina ez da ohikoa.
Bizi diren testuinguruan ez dutenez barneratzen, berdinen artean taldekatzeko joera dute, hau da, lagunarteko zirkulua bakarrik dauden beste adingabe eta gazte atzerritarretan oinarritzen da, errazagoa baita pertsona autoktonoen talde batean sartzen saiatzea baino. Neurri batean positiboa da, baina arriskutsua ere izan daiteke. Positiboa, aisiarako laguntza- eta konpainia-sare bat izate hutsagatik, baina baita arriskutsua ere, denek baitituzte antzeko egoerak, eta, oro har, premia handiak, eta bizirik irauteko senak iraganaldi txarrak izan ditzake. Horrela taldekatzeak, talde bateko kide izatearen sentimendu horretatik eta, hala badagokio, talde bateko ohiturei, kulturari eta abarri eusteko aukera emango duen talde batengandik duten beharragatik ere gertatzen da, eta horrek, neurri batean, migratzea erabakitzean utzi dutenetik hurbilago sentiarazten ditu. Izan ere, Barrón eta Sánchez Morenok (2001) gogoarazten digutenez, bizitzako gertaera estresagarriek zuzeneko lotura dute narriadura psikologikoarekin eta depresioarekin, eta, gizartelaguntza handiagoa izanez gero, zauria murrizten da. Gizartean eta komunitatean gutxi parte hartzen dute, ez zaielako aukerarik ematen; izan ere, beren egoera dela eta, ez dira komunitatean ondo integratuta dauden pertsonak. Manzani eta Arnosoren ideiarekin bat (2014), elkarrizketatuen aburuz gizarte-estigma hain da negatiboa non gizarte-rolak betetzeko mugatuta sentitzen diren; horregatik, nahiago dute beren taldeetan jarraitu, hots, estereotipo horiek etengabe frogatu edo gezurtatu beharrik ez duten taldeetan jarraitu.

Bakarrik dauden gazte atzerritarrei buruzko informazio teoriko eguneratua bilatzeak izan duen zailtasuna azpimarratu nahi genuke, ikasketa gehienak bakarrik dauden adingabe atzerritarrei begira baitaude. Gainera, ezin izan dugu kolektiboari buruzko egungo datu kuantitatiborik aurkitu, hutsune handia baitago arlo horretan. Informazio falta hori konpentsatzeko, ezinbestekoa izan da profesionalen elkarrizketetarako sarbidea izatea; izan ere, lehenago aipatu dugun bezala, errealitatera hurbiltzeko eta kolektiboaren egoera hobeto ulertzeko aukera eman digu.

Alderdi asko aldatzen saiatzeaz gain (erregularizazioa, laneratzea...), zalantzarik gabe, lehen pausoa gizarte-estigma eta kolektibo horren inguruko estereotipoak haustea da. Batzuetan egiaztatu ahal izan dugu estigma sozialak egitura bera baino oztopo gehiago sortzen dituela, gazte horiei ez baitzaie aukerarik ematen erakunde edo entitateetatik kanpo. Gure testuinguruan, komunikabideek mesede eskasa egiten diete kolektibo honen gizarteratzeari, titularrak alarmistak, sentsazionalistak eta helburu gutxikoak baitira, estigma negatiboa baino sustatzen ez dutelarik. Horregatik, gizarte hezitzaile garen aldetik, gizartea sentsibilizatu behar dugu, kulturarteko harremanak eta laguntza-sareak erraztu eta sustatu behar ditugu, estereotipo horiek suntsi daitezen, eta bakarrik dauden gazte atzerritarrak pertsonalki gara daitezen, beste edozein pertsona bezala. 
Nahiz eta gure lanarekin kolektibo honen beharrizanak gehiago zehaztu, gaur egun Bizkaian ematen hari den fenomeno hau gehituz joango $\mathrm{da}$, hau da, gero eta profil honetako gazte gehiago egongo dira eta hainbat gaietan sakontzea beharrezkoa izango da, haien egoera hobetzeko eta giza eskubideak mantentzen direla ziurtatzeko.
Aztertzeko puntuetako garrantzitsuenetariko bat da etorkizuneko ikerketetan, hau da: bizitzaren zail guztietan, bizi-etapa guztietan,transbertsalki aztertzea zelan lortzen duten aurrera egitea, zeintzuk diren aurrera egiteko faktoreak; eta zein faktore oztopatzen duten prozesua bera. 
ALBERICH, T. (2007): "Investigación-Acción Participativa y mapas sociales", <http:// comprenderparticipando.com/wp-content/ uploads/2016/04/Tomas-Alberich-NistalInvestigacion-accion-participatival.pdf〉.

ALCÁNTARA, G. (2008): "La definición de salud de la Organización Mundial de la Salud y la interdisciplinariedad", Sapiens, 9. lib., 1. zb., 93.-107. or., <https://www.redalyc.org/ $\mathrm{pdf} / 410 / 41011135004 . p d f$.

ARARTEKO (2011): Arrisku egoera berezietan dauden adingabeak, Txosten Bereziak saila, Gazteiz, Ararteko, 〈https://www.ararteko.eus/ RecursosWeb/DOCUMENTOS/1/0_2354_1.pdf〉.

BARRÓN, A. eta SÁNCHEZ MORENO, E. (2001): "Estructura social, apoyo social y salud mental", Psicothema, 13. lib., 1. zb., 17.-23. or.

BLANCAS, R. eta JURADO, G.B. (2010): "Estrategias de intervención social con jóvenes inmigrantes ex tutelados por el Servicio de Protección de Menores", Documentos de Trabajo Social, 47. zb., 134.-143. or.

BRICEÑO-LEÓN, R. (2000): "Bienestar, salud pública y cambio social", in BRICEÑO, R.; DE SOUZA, M., eta COIMBRA, C. (ed.), Salud y equidad: una mirada desde las ciencias sociales, Rio de Janeiro, Fiocruz, 15-24. or.

CONSEJO GENERAL DE LA ABOGACÍA ESPAÑOLA eta UNICEF ESPAÑA (2009): Ni ilegales ni invisibles: realidad jurídica y social de los menores extranjeros en España. Informe 2009, 〈https:// www.abogacia.es/publicaciones/informes/ informes-fundacion-abogacia/ni-ilegales-niinvisibles-realidad-juridica-y-social-de-losmenores-extranjeros-en-espana/>.

EUSKO JAURLARITZA. (2019): Instrumento Técnico Común de Valoración de la Exclusión Social, Gasteiz,
Berdintasun, Justizia eta Gizarte Politiketako Saila, «https://www.euskadi.eus/contenidos/ informacion/instrumento_valoracion/ es_instrume/adjuntos/Instrumento $\% 20$ valoracion $\% 20$ exclusion $\% 20$ social-junio $\% 20$ 2012.pdf

LAFUENTE, E.M. (2010): “Menores inmigrantes no acompañados (MENAS)", Fòrum de Recerca, 15. zb, 495.-504. or., <http://hdl.handle. net $/ 10234 / 77768>$.

MANZANI, L. eta ARNOSO, M. (2014): “Bienestar psicosocial en menores y jóvenes extranjeros sin referente familiar adulto: factores de riesgo y protección”, Norte de Salud Mental, XII. lib., 49. zb., 33.-45. or.

MARKEZ, I. eta PASTOR, F. (2009): Drogodependencia en menores extranjeros no acompañados (MENA), Gasteiz, Eusko Jaurlaritzaren Argitalpen Zerbitzu Nagusia, 〈https://www. euskadi.eus/gobierno-vasco/-/libro/drogamendetasuna-inoren-kargura-ez-daudenadingabe-atzerritarrengan-ikedaa-kalitatezkohezkuntzarako-eta-osasunerako-eskubideadrogodependencia-en-menores-extranjerosno-acompanados-mena-su-derecho-a-unaeducacion-y-salud-de-calidad/s.

PALMA-GARCÍA, M.O.; RUIZ MOSQUERA, A.C., eta VIVES GONZÁLEZ, C.L. (2019): “Jóvenes inmigrantes extutelados. El tránsito a la vida adulta de los menores extranjeros no acompañados en el caso español", Revista Internacional de Políticas de Bienestar y Trabajo Social, 12. zb., 31.-52. or., 〈https://doi.org/10.15257/ ehquidad.2019.0009'.

SAVE THE CHILDREN (2017): Los más solos, Madril, Save the Children España, 〈https://www. savethechildren.es/sites/default/files/imce/ los_mas_solos_vok.pdf〉. 
SENOVILLA, D. (2007): Situación y tratamiento de los menores extranjeros no acompañados en Europa, Brusela, Observatorio Internacional de Justicia Juvenil, 〈https://www.oijj.org/ centro-documental/docs/general/situaciony-tratamiento-de-los-menores-extranjeros-noacompanados-en>.

SETIÉN, M.L.; eta BARCELÓ, F. (2008): “La atención a los menores extranjeros no acompañados en el País Vasco: modelos de intervención y luces y sombras del sistema de acogida", E-migrinter, 2. zb., 78.-88. or.

STEIN, M. (2006): "Research review: Young people leaving care", Child \& Family Social Work, 11. lib., 3. zb., 273.-279. or., <https://doi.org/10.1111 /j.1365-2206.2006.00439.x〉.
UNESCO (2020): Inclusión y educación: todos y todas sin excepción, Paris, Unesco, 〈https://unesdoc. unesco.org/ark:/48223/pfooo0374615'.

VINAIXA, M. (2019): “La mayoría de edad: un mal sueño para los menores extranjeros no acompañados", Cuadernos de Derecho Transnacional, 11. lib., 1. zb., 571.-602. or., <https://doi.org/10.20318/ cdt.2019.4633>.

WELLER, J. (2007-2008): “La inserción laboral de los jóvenes: características, tensiones y desafíos", Revista de la CEPAL, 92. zb., 61.-82. or., <http:// hdl.handle.net/11362/37458>. 